\title{
Developing a Management System for assessing Dam Safety in Iraq
}

\author{
Ali Salman Mahdi ${ }^{1 *}$ Sedki Esmaeel Rezouki ${ }^{2}$ \\ ${ }^{1,2}$ Civil Eng. Dept., College of Engineering, University of Baghdad, Baghdad, Iraq \\ ${ }^{1}$ Email: ali.eng560@yahoo.com \\ 2Email: sedki_razqi@yahoo.com \\ *Correspomding Author.
}

\section{Abstract}

The evolution of the concept of management of safety of dams in the world Rating with the evolution of lifestyles and the increasing number of dams and sizes and multiple purposes, which has set up for it, for the purpose of maintaining the facility and their durability in the form required for the continuation performed for the purpose for which it created for him and the preservation of the lives of people and property from the dangers of these dams partially or totally. It is in order to keep pace with global developments in this field has been the development of an administrative system to evaluate the safety of dams in Iraq, in the theoretical side a literature review and concepts on the safety of dams where has been done in the research, but in the practical side an open questionnaire through frequent visits to the dams and departments responsible positions are done and then hold a closed questionnaire through its own form of a questionnaire distributed this purpose, the experts and practitioners in the field of dam safety in the administration of Iraq, reached a researcher to develop a system to evaluate the safety of dams keep pace with global developments in this field and meets the requirements of management the safety of dams in Iraq.

Keywords: Dam safety, Risk assessment, Dam safety Obstacles, Dam safety principles

\section{Research Hypothesis}

We can formulate the research hypothesis as follows (there are obvious weakness in the management of dam safety in Iraq assessing with clear late for global development in this area, which led to the emergence of the urgent need to preserve this important property in the development of a sophisticated system to assess the safety of dams in Iraq, a system that meets the requirements needed In this area)

\section{Introduction}

The importance of dams in all countries of the world lies in two aspects as it provides drinking and irrigation water and the intervention in fisheries development and provision 
of tourist atmosphere in addition to the provision of electric power and improving the environment, and the other hand, maintain the life of the people of the risk of flooding and to reduce these risks to a level that does not threaten people's lives and property. From this point the development of management systems for assessment of dam safety become an important key factor in the preservation and continuation of the elements of performance. The researcher has developed a management system to evaluate the safety of dams in Iraq meets the requirements of the required safety and security and maintain the dams in this country, taking into consideration keep pace with global developments in this field.

\section{The Objectives of the research:}

Planning to manage dams in lifelong cycle in correspondence with regulatory necessity, company standards, in this framework, with obligation to Communities interesting, and sound engineering and pertaining to the environment practices. Planning for final closing, involving:

1 - Safeguarding of overall health of the community and safety.

2 - Relaxation of contrary ecological effects of this action or project.

3 - Satisfactory post closure utilize in an achievable applied and economic system.

Recognize and estimate consequential pertaining to the environment, wellness and security point of view and the connected risks.

\section{The concept of dam safety}

The safety of the dams of the most important things that are taken into consideration in all over the world have grown in importance with the increasing number of dams and their types and degree of danger to life and property, in order to maintain the integrity of dams and make them work properly in order to fulfill the purposes that have established for it and thus to maintain the population and property of this collapse of dams risks [1]. As well as numerous types of systems administration to the safety of dams in the world evaluate and depending on the nature of economic and political systems and environmental and social management and the importance of dams and study the risks From this point will be discussed in this chapter to public order and destruction to evaluate the safety of dams and general goals and fundamental principles and basic parts in general to regulate the administration to dam safety evaluation of on the part of the general concept for the safety of dams.

\section{1- Concept of risk assessment for dams}

Risk assessment is the process of deciding whether existing risks are resignation and present risk control action are reasonable or not, and whether alternative risk control 
measures are expect. Risk assessment encompass, as inputs from the risk analysis and risk evolution stage [1]. Risk assessment involves making judgement about the taking of risk and all parties must recognize that the difficult attendant might occur and owners will be demand to deal effectively with consequences of the failure incident. Risk analysis is used for implementing safety assessment for many contrasting technical systems. In recently, the concept has start to fulfil more acceptances within the class of water resources management agencies. The importance of a dam failure are, on the one hand, the losses of the dam owner due to failure of the dam and / or power plant( e.g. loss of energy production, loss of water supply, etc.), and on the other hand the losses caused by a flood wave in the downstream region of the dam. The losses in the flood plain can be summarized as follows [3, 4]:

1. Loss of live.

2. Environment damage.

3. Property damage in flood plain.

4. Damage of infrastructure in flood plain.

5. Socio - economic impact.

6. Political impact.

Normally, the losses in the flood plain greatly those of the dam owner. In certain, there are different types of losses, such as loss of life, ecological damage, etc., where quantify them cannot be easily. The economic losses of a dam failure can covered by insurance industry. Such insurance intrigue exit in several countries. The losses of the owner and limited economical losses in the flood plain covered by Insurances. An overview of the main part of the risk assessment, which includes the risk analysis and the risk evolution as explained in figure (1).

\section{2- Dam safety objective}

The process of guard people, property and the environment from the harmful effects of disoperation or failure of dams and reservoirs called with dam safety objective, this important objective can be reached by controlling the stored volume of water and controlling all flows through and around the dam within specified limits. It has 


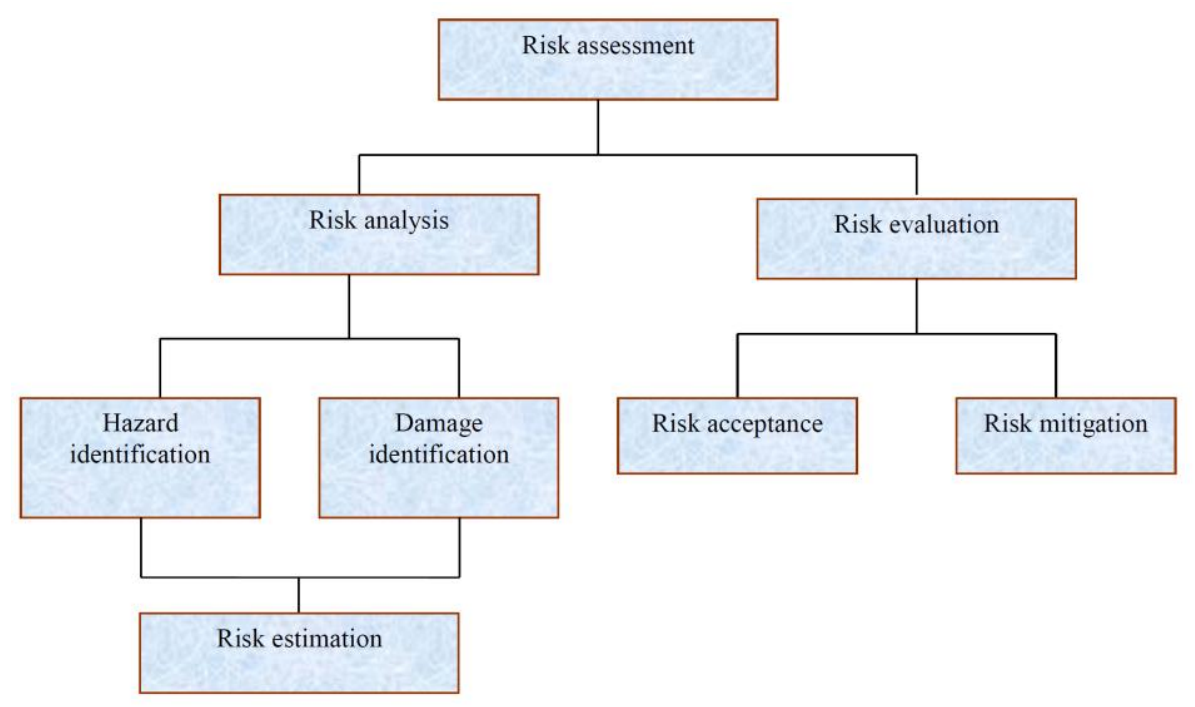

Figure 1: Risk Assessment Flowchart

To be achieved without unduly constrain the operation of dams and reservoirs or the implement of operations that create the benefits of taking the dam safety risks [5]. To ensure that dams and reservoirs are operated and that activities are conducted so as to achieve the highest standards of safety that can reasonably be achieved, measures have to be taken to achieve the following three essential safety objectives [6]:

To control the release of damaging discharges downstream of the dam, to restrict the likelihood of events that might lead to a loss of control over the stored volume and the spillway and other discharges, to mitigate through onsite accident management and/or emergency planning the consequences.

\section{3- Dam safety principles}

The safety philosophy in common represented with set of nine principles have been modelled on the application of general safety standards for hazardous installations. Safety requirements for dams can be developed based on these nine principles, and safety measures implemented in order to attain the essential safety objective. The safety principles form a set that is relevant in its entirety; Even though in practice varied principles may be more or less significant in relation to particular conditions [7] and [8].

Principle 1: Responsibility for dam safety

The main responsibility for dam safety should rest with the entity responsible for the dam and the activities that cause the risks responsibility for dam safety should be obviously defined. Assuring the safety of the public, property and the environment, around and downstream of dams eventually is the responsibility of the Government.

Principle 2: Role of government 
The overarching structures for dam safety assurance provided by legal and governmental framework for safety, a properly established legal and governmental framework provides for the regulation of dams and reservoirs, and associated operational activities that can cause a dam breach and other overwhelm risks, and for the obvious assignment of responsibilities.

Principle 3: Leadership and management for safety

Successful leadership and management for safety should be established and confirm in organizations responsible for dam risks In common, Demonstrated at the highest levels in all organizations with responsibility for dam safety risks are the main adjectives of a leadership in safety matters.

Principle 4: Justification for dams and reservoir

Dams, reservoirs and activities that induce dam safety risks should give an overall benefit to society. The dam constructions inconvenience risks on society, in normally the distribute of these risks are irregular, as example those who gain from the dam are not compulsory those on whom the risk is imposed.

\section{Principle 5: Optimization of protection}

Protection should be ideally to provide the highest level of safety that can quietly be achieved is highly recommended. The safety criterion that are impose to dams, which cause societal risks, are look at to be optimized if they yield the maximum level of safety that can quietly be achieved throughout the lifetime of the dam, without placing an unreasonable burden on society and without excessive limiting its utilization.

Principle 6: Limitation of risk to individuals measures for controlling dam safety risks should ensure that no individual bears an unacceptable risk of harm.

Protections Justification and optimization do not in themselves ensure that no individual, including employees and operators, bears an unreasonable risk of harm. From the definition of Risk Limits, where its typically represent a valid upper edge of acceptableness, they are inadequate in themselves to guarantee the best to be accomplish protection due to certain reasons and they therefore they must be add on to by the optimization of protection. Therefore, both the optimization of protection and the limitation of risks to individuals are essential to achieve the request degree of safety [9, 10].

Principle 7: Protection of present and future generations People, property and the environment, present and future, should be protected against the effects of dam failures and other reservoir risks.

The fact of dam safety management decisions made in the present will affect future generations must be taken in account, and therefore have effects that extend across many 
human generations. In a similar manner, dams are not benign concerning to the environment and the long-term risks to the environment must also be thought over carefully.

Principle 8: Prevention of accidents all reasonably practicable efforts should be made to prevent and mitigate dam failures and accidental releases.

To make certain that the possibility of an accident having harmful result is extremely low, measures have to be taken to obtain the following: to prevent the incident of failures or abnormal conditions (including breaches of security) that could lead to not controlled release of all or part of the stored volume; to avoid the rise of any such incidents or unusual conditions that does happen $[3,11]$.

Principle 9: Emergency preparedness and response.

Suitable arrangements should be made for emergency readiness and reaction for dam failures and accidental releases. The initial goals of readiness and reaction for a dam breach emergency are as follows $[12,13]$ :

1. To make certain that arrangements are in situated properly for an efficient reaction located at the place and, as appropriate, at the local, regional, national and international levels, to a dam breach emergency.

2. To guarantee that, for reasonably predictable incidents, flooding result would be minimize.

3. for any incidents or failures that do happen, to take applicable measures to mitigate any result for human life and health, property and infrastructure, and the environment.

\section{6- The field study}

In order to identify the most important obstacles to evaluate the safety management of dams in Iraq and through the main axes (planning, organization, control and follow-up) has been studied through field survey and questionnaire that included open and closed questionnaire.

\subsection{Open questionnaire:}

The open questionnaire preparing through:

1. Homeliness through frequent field visits for a period of six months for details on the process of safety assessment in Iraqi's dams and study records, annual reports, repairs and Periodical reports.

2. Open conduct personal interviews with engineers and workers who have experienced and competence and the use of their performance and suggestions on Preparation and form a closed questionnaire and the election of the research sample. 


\subsection{Preparation of the closed form of a questionnaire}

Based on the results that have been obtained through an open questionnaire and theoretical study then we were able to prepare the closed questionnaire.

Where they were divided into two parts as following:

1. First Section: It includes general questions about personal information of questionnaire sample, which include department name or the workplace, educational attainment, General Specialization, net Specialization as well as the exact job position and the number of years of experience in the field of dam safety evaluation.

2. Second section: It includes a questionnaire on the obstacles that prevent the development of management system for evaluation the safety of dams in Iraq: these obstacles consist of:

(a) Obstacles in the field of Planning, consists of 14 items.

(b) Obstacles in the field of organization, consists of 13 items.

(c) Obstacles in the field of control and follow-up, consists of 14 items.

Likert scale method used to measure the responses of the respondents to the questionnaire according to the table (1). Then giving weight to each answer to convert qualitative answers to quantitative answer.

Table 1 Likert scale Degrees (Likert Scale)

\begin{tabular}{|l|l|l|l|}
\hline Response & Yes & No & Maybe \\
\hline degree & $\mathbf{5}$ & $\mathbf{1}$ & $\mathbf{3}$ \\
\hline
\end{tabular}

6.3 Statistical analysis and discus of the answers to the questionnaire

To identifying the results that emerged from the closed questionnaire process was necessary to analyze the answers of the questionnaire using simplified statistical, therefor the researcher used statistical program (The statistical package of social science (SPSS)) Statistical analysis has included two parts to form a closed questionnaire by:

1. Statistical analysis and discus for questionnaire sample.

2. Statistical analysis and discus of the Answers about the questionnaire areas.

\subsubsection{Statistical analysis and discus of personal data}

Researcher found through analysis of answers of questions about personal data as shown in tables (2), (3), (4) and (5) 
Table 2: Specialization.

\begin{tabular}{|l|l|l|}
\hline Specialization & Frequency & Percent\% \\
\hline Civil engineering & 37 & 35.24 \\
\hline Electricity Engineering & 21 & 20 \\
\hline Mechanical Engineering & 16 & 15.24 \\
\hline Geological & 16 & 15.24 \\
\hline Programmer & 15 & 14.28 \\
\hline Total & 105 & 100 \\
\hline
\end{tabular}

Table 3: Educational attainment.

\begin{tabular}{|l|l|l|}
\hline Academic degree & Frequency & Percent\% \\
\hline Technical Diploma & 20 & 18.1 \\
\hline BSC & 42 & 40 \\
\hline MSC & 26 & 24.76 \\
\hline PhD & 17 & 17.14 \\
\hline Total & 105 & 100 \\
\hline
\end{tabular}

Table 4: Years of Experience.

\begin{tabular}{|l|l|l|}
\hline Years of experience & Frequency & Percent \\
\hline-10 years & 12 & 11.44 \\
\hline-15 years & 28 & 26.66 \\
\hline-20 years & 35 & 33.33 \\
\hline more than 20 years & 30 & 28.57 \\
\hline total & 105 & 100 \\
\hline
\end{tabular}

Table 5: Career post.

\begin{tabular}{|l|l|l|}
\hline Job title & frequency & Percent \% \\
\hline General manager & 4 & $3.81 \%$ \\
\hline $\begin{array}{l}\text { Assistant general } \\
\text { manager }\end{array}$ & 9 & $8.57 \%$ \\
\hline Project manager & 5 & $4.76 \%$ \\
\hline Head of department & 15 & $14.28 \%$ \\
\hline Head of division & 32 & $30.47 \%$ \\
\hline others & 40 & $38.11 \%$ \\
\hline Total & 105 & $100.00 \%$ \\
\hline
\end{tabular}

\subsubsection{Statistical analysis and discus of the questionnaire fields}

The second section of the questionnaire, containing the triple fields to the main impediments to evaluate the safety management system of dams in Iraq, the researcher used the statistical program SPSS. 
The percentage is calculated for the answers to the questionnaire for each axis of the axes of dam safety evaluation (planning, organization, control and follow-up) where every Obstacle taking a sequence according to the relative importance and as shown in Tables A1, A2 and A3, The following are the results of the analysis of the answers:

Obstacles in the field of planning: is clear from Table (A-1) that the average degree of responsive the study sample on this field Reached (3.41) and The relative weight of this field was $(68.27 \%)$ as it set out in table (6).

Table 6: Obstacles in the field of planning.

\begin{tabular}{|l|l|l|}
\hline Field & Mean of Relative Importance of & The average approval rate \\
\hline obstacles in planning & $68.27 \%$ & 3.41 \\
\hline
\end{tabular}

Obstacles in the field of organization: It's clear from table (A-2) the average degree of response in the study sample in this field reached (3.99), and the average relative importance (79.78\%) as shown in the table (7)

Table 7: Scarcity develops clear plans concerning Program of dam safety evaluation during

\begin{tabular}{|l|l|l|}
\hline Field & Mean Relative Importance & The average approval rate \\
\hline Obstacles in the organization & 79.78 & 3.99 \\
\hline
\end{tabular}

Obstacles in the field of control and follow-up: Table (A-3) shows the results of the statistical analysis of the obstacles in the field of control and follow-up in the study sample reached (3.98) and the average relative importance was $(78.88 \%)$ as shown in the table (8).

Table 8: Obstacles in the field of control and follow-up.

\begin{tabular}{|l|l|l|}
\hline Field & Relative Importance & The average approval rate \\
\hline Obstacles in the field of control and follow up & 78.88 & 3.94 \\
\hline
\end{tabular}

Order obstacles, according to the power of influence the researcher studied what fields get the highest score from the study sample point of view, then found the value of the arithmetic mean of the response, standard deviation and relative weight as shown in the table (9).

Table 9: The order of the obstacles by the power of influence.

\begin{tabular}{|l|l|l|l|l|}
\hline Field & avg. & S & RII & Ranking \\
\hline obstacles in the field of organization & 3.99 & 0.603 & 79.78 & 1 \\
\hline obstacles in the field of control and follow-up & 3.94 & 0.567 & 78.88 & 2 \\
\hline obstacles in planning & 3.41 & 0.55 & 67.27 & 3 \\
\hline The total score to respond & 3.78 & 0.462 & 75.56 & \\
\hline
\end{tabular}


It is clear from the table that the areas of the questionnaire vary in terms of strength, where the average degree of approval for all areas reached to (3.78) and relative weight reached to $(75.56 \%)$, fields have been ordered in descending order according to their impact strength in table (9).

The results show that regulatory obstacles are the most important among the results because there are no competent departments in dam safety assessment and dispersion of experiences between the sections in this field, the field of control and follow-up came in the second degree for the lack of central control controls the dam safety evaluated through the use of appliances and equipment advanced, either planning axis came in the third stage of the lack of relevant dimensions of strategy and clear plans in this area provides the conduct of the process of assessing the safety of dams in the desired direction while keeping abreast of global developments in this area.

\section{The proposed administrative system:}

Researcher developed a management system keep pace with global developments in the field of dam safety assess in Iraq, which has become an urgent need under the evolution in the field of dams in Iraq as a result of the need to establish these dams system is divided into three axes according to the areas of management of dam safety, which have been mentioned in the questionnaire assessment as follow:

Organization: The researcher developed an administrative structure for the management of dams, General Authority for dams and reservoirs (MOWR) which takes into consideration the importance of developing a specialized department in the management of dam safety assessment and as shown in Figures (2) and (3).

Control and follow-up: The researcher developed a centralized system for process control and follow-up brings together all the dams and main departments and sub departments in one administration, take into account the process of controlling by agencies and individuals on an ongoing basis without interruption 24 hours per day with processes of documentation and electronic archiving of all information, as shown in Figure (4).

Planning: The proposed system works to address the disadvantages of the current system through the use of modern systems in the planning process, with a necessary correction on an ongoing basis in order to thirsty walk the right path keep pace with the global developments in this field, as shown in Figure (5). 


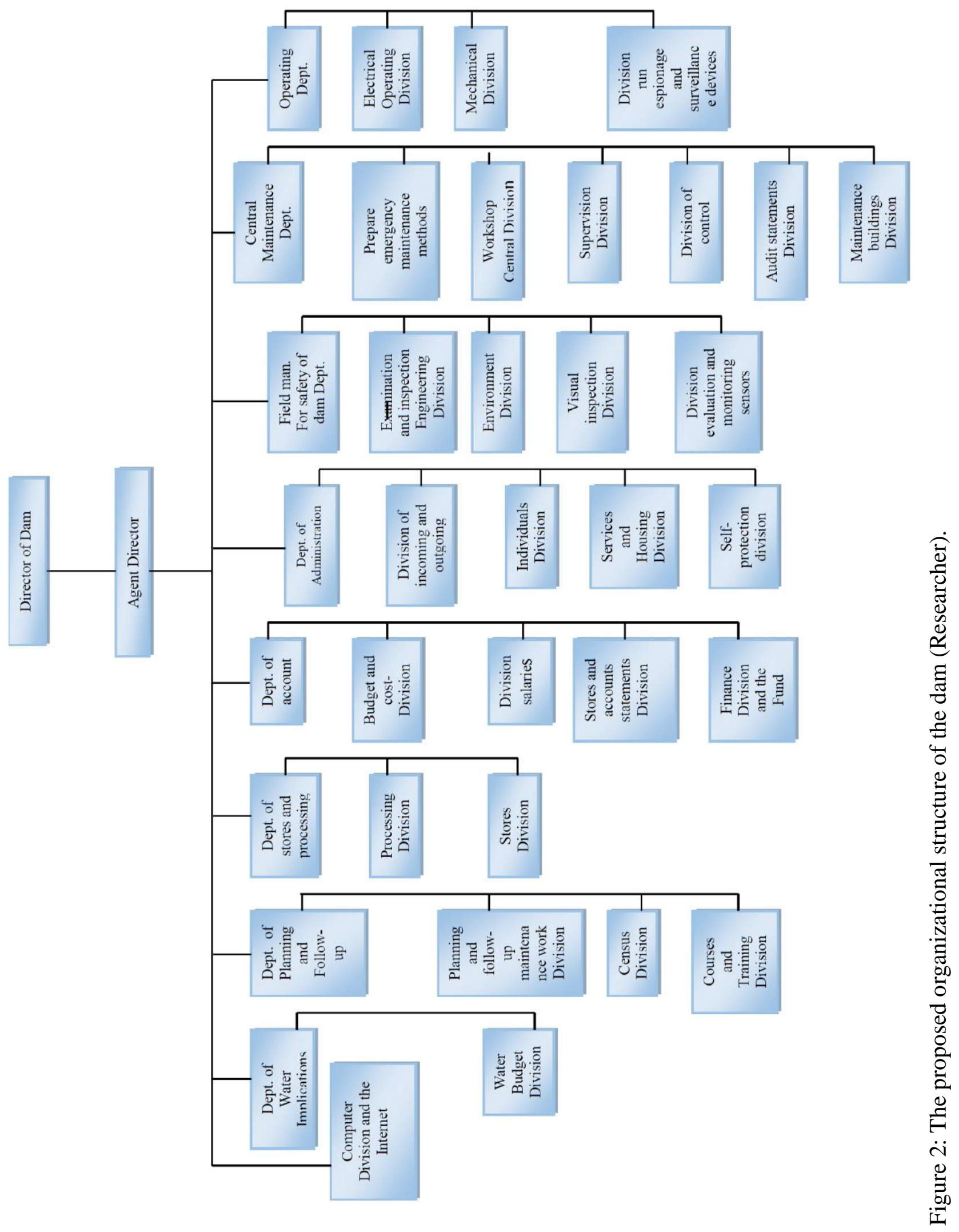




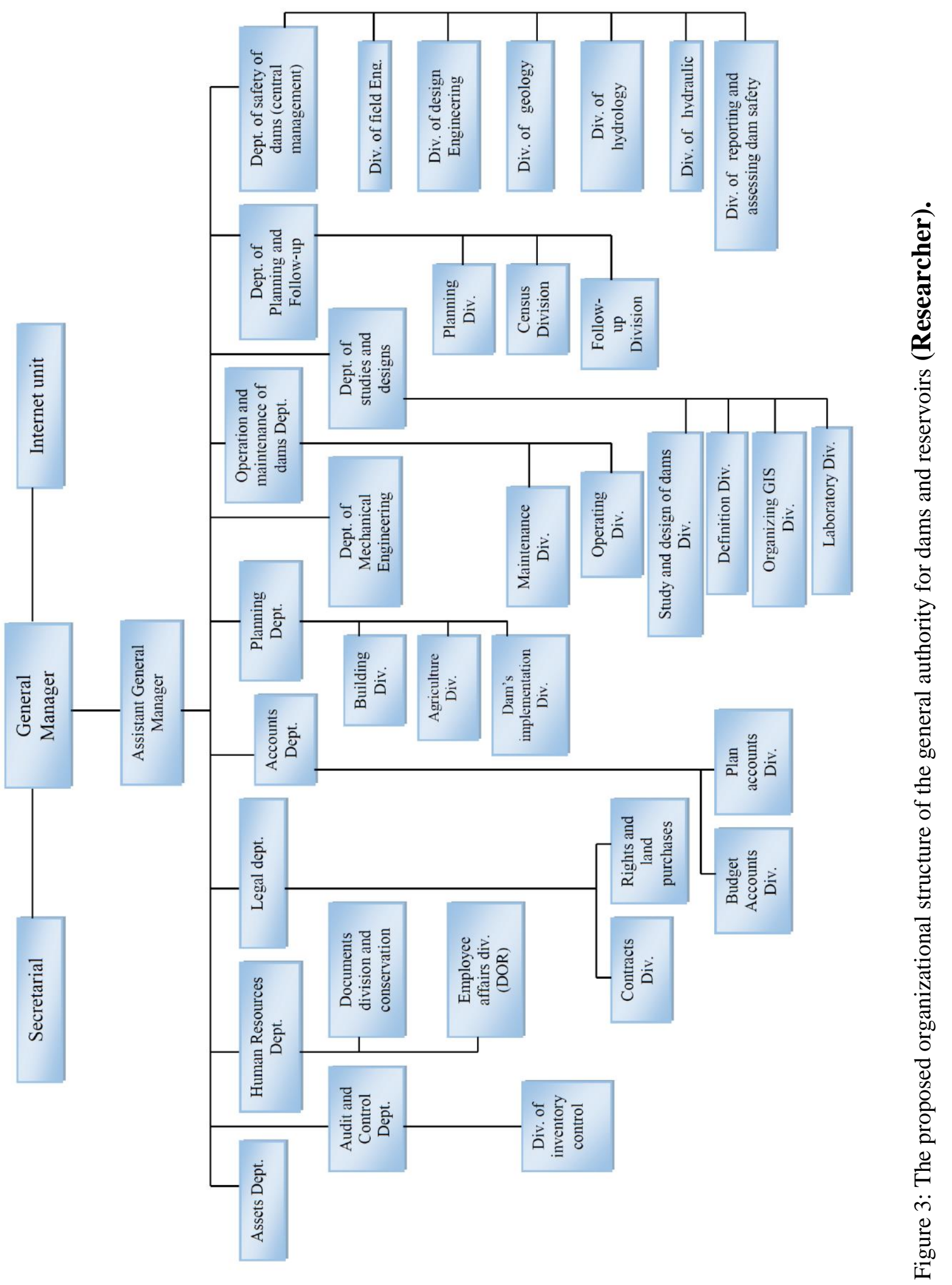




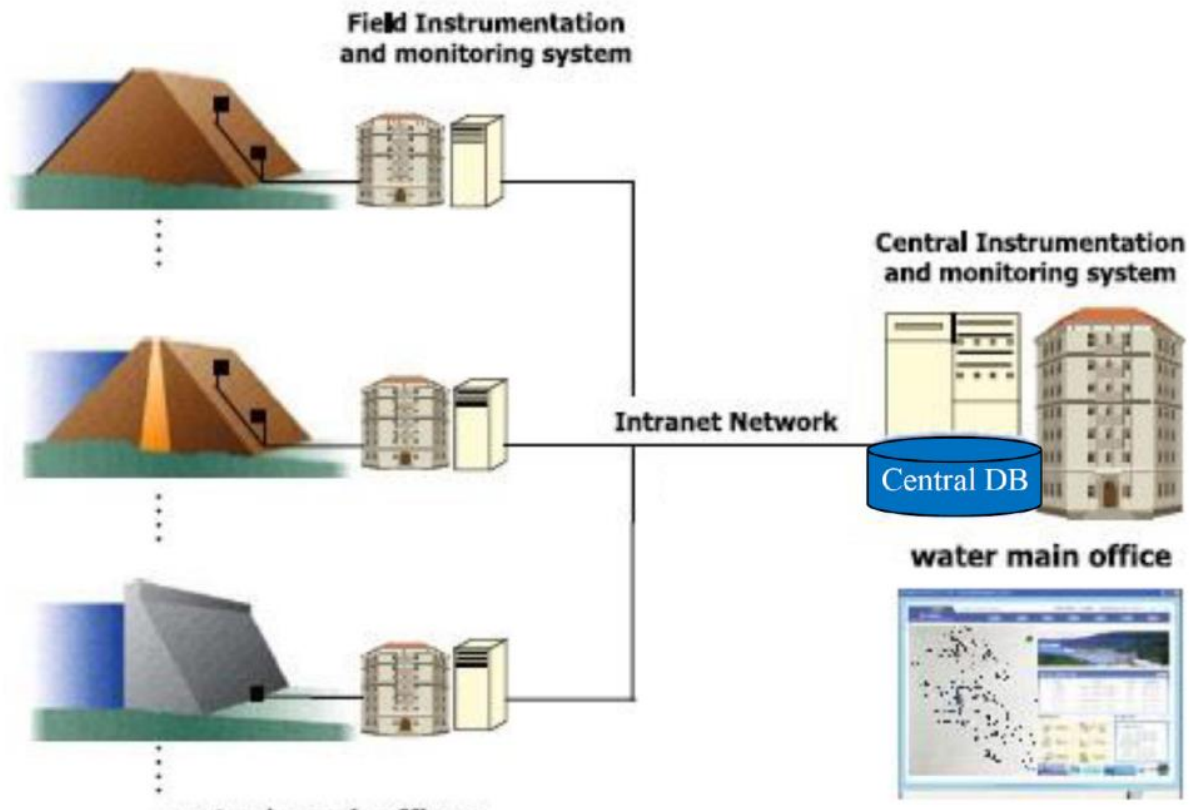

Figure 4: Schematic diagram of data transition and work flow of instrumentation and monitoring

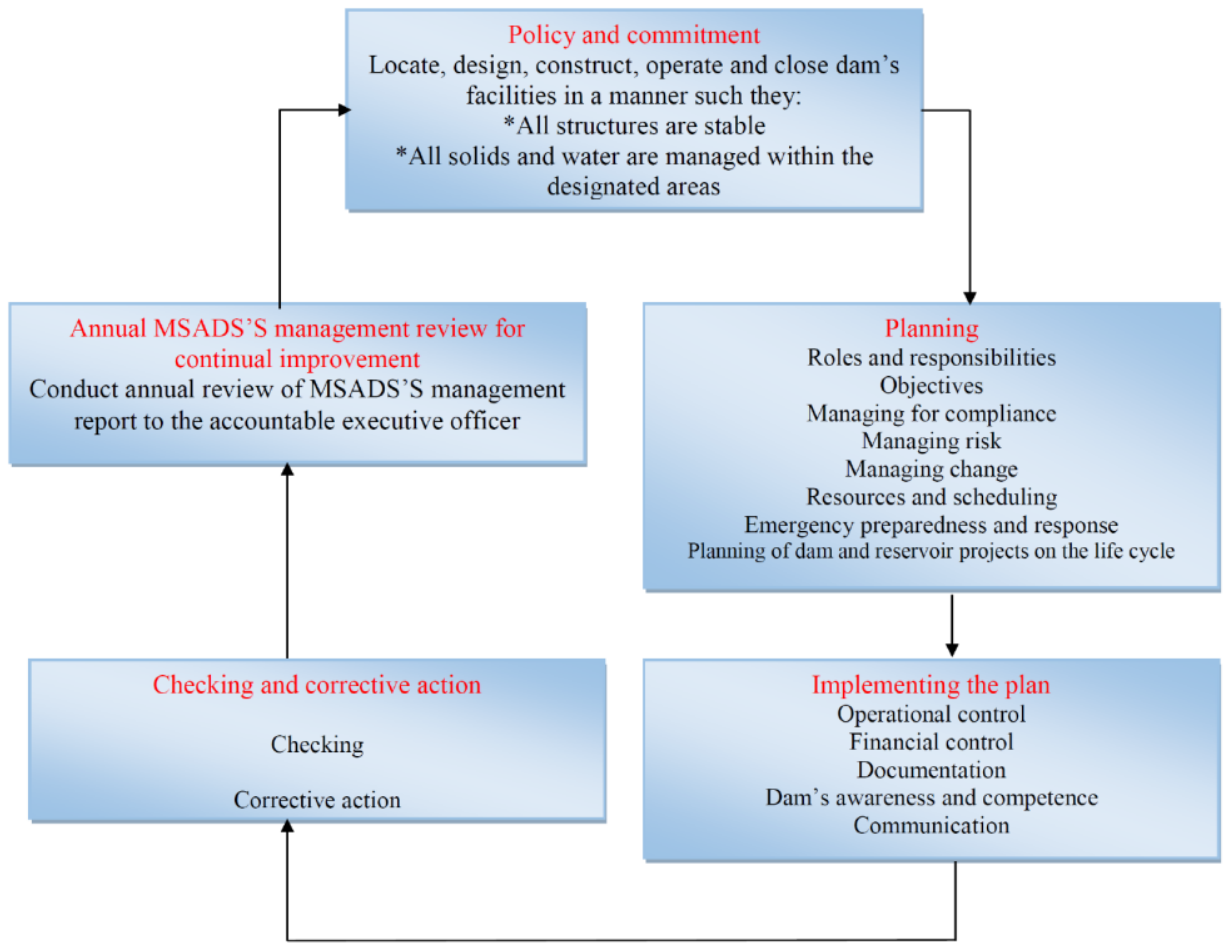

Figure 5: Elements of the management framework (Researcher).

\section{Conclusions}

1. Weakness in the integration planning process to the process of dam safety in Iraq and the failure to observe the main aspects and took priority in terms of importance to the safety of dams. 
2. The lack of clear integrated plans in the risk management process where there is no risk management process, especially during crises and emergency (contingency plan).

3. There are no systematic process for the purpose of conducting business change in safety systems both in the management system or hardware and equipment.

4. Decrease in process control and follow-up on the operating business in accordance with the evolving global systems in this field.

5. Consequently, there is no integrated system to evaluate the safety of dams in Iraq keep pace with global development with clear goals with the lack of laws and regulations in this field.

6. There is no special centralized management of the safety of dams in Iraq as a result of the absence of a Section of the Department dam safety evaluation of Management therefore responsibilities for the management of dam safety dispersed among other sections.

7. Weak central control and monitoring as a result of non-use of a central control device via satellite using modern methods in this field

\section{Recommendations}

The overall recommendations are:-

Applying the proposed management system and actions.

Modifying the organizational structure for general authority for dams and reservoirs and management for the dams according to research trends.

The conditions of the definition of workers in the field of dam safety evaluation of the proposed system in all ministries concerned and linked with each other, according to the proposed system and special partitions used According to the new structure and proposed.

Keep pace with global developments in the field of dam safety through the use of modern technologies for the sustainability of the system works in proposed suggested way and get results.

Hold training courses for workers in the field of dam safety inside and outside the country to assess the increase in the lectures and expertise in this field.

\section{References}

[1] Dawdy, D.R. and lethenmaier, D.P (1987), "Initiative for risk- based flood design." journal of hydraulic engineering, vol.8, 1041- 1051.

[2] Rasheed, Maha A.h. (1999), "Transient simulation and hypothetical model for al- adhaim dam - break," in $\mathrm{PhD}$ thesis submitted to the department of building and construction engineering in the University of Technology. 
[3] Kreuzer, H. and Bury k. (1984), "A probability based evaluation of the safety and risk existing dams." proceedings of the international conference of safety of Dams, Coibre. 23National research council, Committee on techniques for estimating probabilities of extreme floods. (1988). "estimating probabilities of extreme floods", methods and recommended research, national academy press, Washington.

[4] Grishin, M. M., (1982), "Hydraulic structures.” Mir publishers, Moscow.

[5] National research council, Committee on techniques for estimating probabilities of extreme floods. (1988), "estimating probabilities of extreme floods." methods and recommended research, national academy press, Washington.

[6] Piner, G.F., and Breclehoeft, J.D. (1968), "Application of the digital computer for aquifer evaluation." water resoursec research, vol. 4, No.5, pp. 1069 - 1093.

[7] Suresh, P. B. and Harr, M.E. (1962), "Transient development of the surface in a homogeneous earth dam." Geo technique, vol. 12, pp. 283 - 302.

[8] State committee for irrigation projects (1999) Civil work, "Civil work." 1st, 2nd and third part.

[9] Y. Z. J. S. D. S. Meng Yang, Xin Qian, “Assessing alternatives for sustainable management of a flood control dam." International Conference on Ecological Informatics and Ecosystem Conservation (ISEIS 2010).

[10] Bacon, J.H. (1997), “Engineering of hazard reduction: A regulator's perspective.” Michael Leonard Lecture. HSE, London.

[11] ANCOLD (1983), "Australian national committee on large dams." Guidelines for Dam instrumentation and monitoring systems.

[12] Eun-Ho Oh, Kyoon-Tai Kim, Kyong-Hoon Kim, Jin-Man Kim, Jin-Woo Cho , "Development strategy of infrastructure risk assessment based disaster response and management system." World Journal of Engineering and Technology Vol.2 No.3B, September 18, 2014.

[13] Jones, J. C. (1999), “An independent consultant's view on risk assessment and evaluation of hydropower projects." in Risk Analysis in Dam Safety Assessment, by Kuo, J.T. and Yen, B.C. (eds.), Water Resources Publications, LLC. ISBN 1-887201-20-3. 


\section{تطوير نظام ادارة تقيييم سلامة السلدود في العراق \\ علي سلمان مهدي صلدقي اسماعيل رزوقي}

قسم الهندسة المدنية , كلية الهندسة, جامعة بغداد

الخلاصة

لقد تطور مفهوم ادارة تقييم سلامة السدود في العالم مع تطور انماط الحياة وازيـاد اعداد السلدود واحجامها وتعدد الاغراض

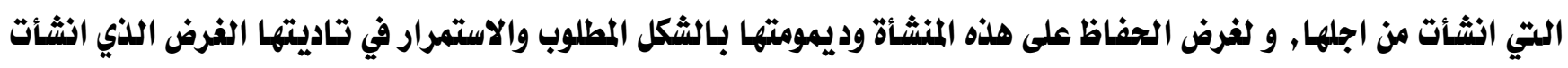

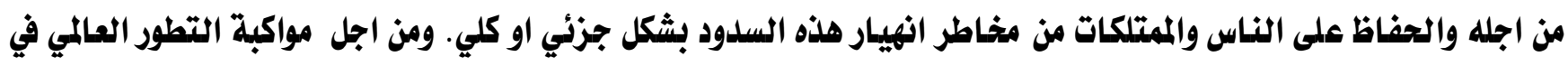
هذا المجال تم تطوير نظام اداري لتقييم سلامة السدود في العراق حيث تم في هذا البحث مراجعة الادبيات والمفاهيم الخاصة

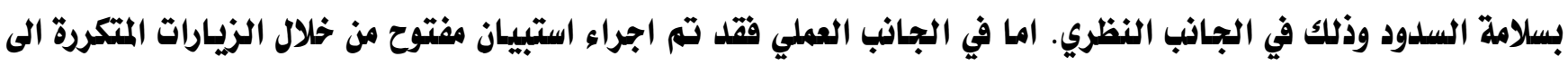

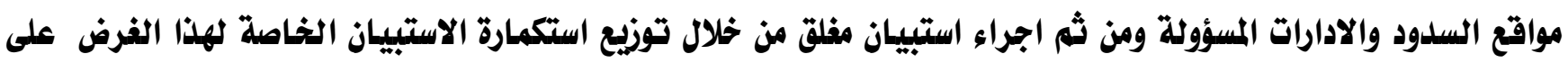

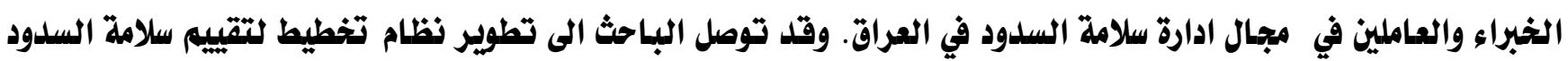

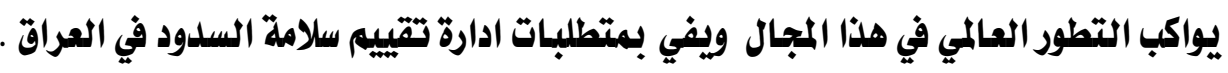




\section{Appendices}

Table (A-1) illustrates the results of the statistical analysis of obstacles to planning

\begin{tabular}{|c|c|c|c|c|c|}
\hline Sequence & Section & Avg. & $\mathbf{S}$ & RII & Ranking \\
\hline 1 & $\begin{array}{l}\text { The lack of a clear plan to develop } \\
\text { modern programs in the safety of the dam } \\
\text { and keep abreast of global developments } \\
\text { in this field evaluation }\end{array}$ & 354 & 0.809 & 70.89 & 4 \\
\hline 2 & $\begin{array}{l}\text { Scarcity of a clear plan concerning dam } \\
\text { safety evaluation program during the stage of } \\
\text { site selection }\end{array}$ & 3.45 & 0.899 & 68.95 & 5 \\
\hline 3 & $\begin{array}{l}\text { Weakness in the economic work of } \\
\text { the project for many dam projects and } \\
\text { follow-up evaluation } \\
\text { of the safety of dams }\end{array}$ & 3.67 & 1.019 & 73.46 & 3 \\
\hline 4 & $\begin{array}{l}\text { Lack of attention to the issue of dam } \\
\text { safety evaluation during the design phase }\end{array}$ & 3.29 & 1.030 & 65.88 & 9 \\
\hline 5 & $\begin{array}{l}\text { Failure to observe aspects of dam safety } \\
\text { and impact the future through } \\
\text { construction of dams stage }\end{array}$ & 3.93 & 1.083 & 78.63 & 2 \\
\hline 6 & $\begin{array}{l}\text { Lack of integrated planning for } \\
\text { the sustainability of the ingredients } \\
\text { sustaining dam safety during } \\
\text { the construction and maintenance phase }\end{array}$ & 3.98 & 1.043 & 79.62 & 1 \\
\hline 7 & $\begin{array}{l}\text { The dearth of clear objectives } \\
\text { regarding the evaluation of } \\
\text { Omar facilities dams }\end{array}$ & 3.24 & 0.997 & 64.71 & 11 \\
\hline 8 & Double the risk of dam management plan & 3.31 & 0.990 & 66.21 & 7 \\
\hline 9 & $\begin{array}{l}\text { The lack of a plan to sustain the processes } \\
\text { of change in the joints of } \\
\text { dam safety management }\end{array}$ & 3.36 & 1.082 & 67.13 & 6 \\
\hline 10 & $\begin{array}{l}\text { The scarcity of the existence of } \\
\text { a contingency plan prepared in a clear and } \\
\text { coach them all the specific departments }\end{array}$ & 3.20 & 1.013 & 64.00 & 13 \\
\hline 11 & $\begin{array}{l}\text { Lack of conformity through the process } \\
\text { of dam safety and for the safety of } \\
\text { administrative laws and regulations } \\
\text { globally recognized rating }\end{array}$ & 3.31 & 1.015 & 66.15 & 8 \\
\hline 12 & $\begin{array}{l}\text { Weakness scheduling requirements } \\
\text { and funding sources dam safety management }\end{array}$ & 3.23 & 1.063 & 64.62 & 12 \\
\hline 13 & $\begin{array}{l}\text { The lack of planned operations liaison } \\
\text { between the designer and the joints } \\
\text { of the management of dams } \\
\text { and consultants through the stages } \\
\text { of the life of dams }\end{array}$ & 3.03 & 1.184 & 60.58 & 14 \\
\hline 14 & $\begin{array}{l}\text { Weak schedule and arrange surveys } \\
\text { and inspections, repairs and } \\
\text { maintenance related }\end{array}$ & 3.25 & 1.125 & 64.95 & 10 \\
\hline 15 & The total score of the field & 3.41 & 0.550 & 68.27 & \\
\hline
\end{tabular}


Table (A-2) illustrates the results of the statistical analysis of obstacles to the field of organization.

\begin{tabular}{|c|c|c|c|c|c|}
\hline Sequence & Section & Avg. & $\mathbf{S}$ & RII & Ranking \\
\hline 1 & $\begin{array}{l}\text { The lack of a special department } \\
\text { to assess the safety of dams }\end{array}$ & 4.20 & 0.969 & 84.04 & 2 \\
\hline 2 & $\begin{array}{l}\text { Weakness in the distribution } \\
\text { of roles and responsibilities }\end{array}$ & 4.00 & 0.914 & 80.00 & 5 \\
\hline 3 & $\begin{array}{l}\text { Scarcity of coordination between } \\
\text { departments and relevant departments } \\
\text { in the evaluation of the safety of dams }\end{array}$ & 3.98 & 0.971 & 79.62 & 8 \\
\hline 4 & $\begin{array}{l}\text { Poor documentation processes and } \\
\text { to address the evolution in this area }\end{array}$ & 4.06 & 0.953 & 81.18 & 4 \\
\hline 5 & $\begin{array}{l}\text { The continued absence in the field } \\
\text { of dam safety development programs }\end{array}$ & 3.82 & 1.007 & 76.38 & 12 \\
\hline 6 & $\begin{array}{l}\text { Lack of specialized cadres adopt } \\
\text { the training and development process } \\
\text { cadres in the field of dam safety }\end{array}$ & 3.60 & 1.075 & 71.92 & 13 \\
\hline 7 & $\begin{array}{l}\text { Scarcity of incentives offered } \\
\text { to employees in the private surveying } \\
\text { the safety of dams and field inspection }\end{array}$ & 3.95 & 1.147 & 78.81 & 10 \\
\hline 8 & $\begin{array}{l}\text { Negative impact of economic and political } \\
\text { situation on the support of creative ideas }\end{array}$ & 4.18 & 1.026 & 83.62 & 3 \\
\hline 9 & $\begin{array}{l}\text { Leave a lot of experiences as a result } \\
\text { of retirement and lack of investment } \\
\text { ideas and experiences with them } \\
\text { as a consultant contract }\end{array}$ & 3.95 & 1.041 & 79.05 & 9 \\
\hline 10 & $\begin{array}{l}\text { There is no central sections } \\
\text { special maintenance in all } \\
\text { its forms manages dams }\end{array}$ & 3.99 & 0.956 & 79.81 & 6 \\
\hline 11 & $\begin{array}{l}\text { Conflicts of dispersion of the special } \\
\text { responsibilities of dam } \\
\text { safety evaluation of sections }\end{array}$ & 3.99 & 0.893 & 79.81 & 7 \\
\hline 12 & $\begin{array}{l}\text { Weakness encouragement to creativity } \\
\text { and patents in the field of dam safety }\end{array}$ & 3.92 & 1.007 & 78.48 & 11 \\
\hline 13 & $\begin{array}{l}\text { Weakness in the distribution of specialized } \\
\text { in dam safety assessment and put them } \\
\text { within the relevant departments } \\
\text { in this area advisory cadres }\end{array}$ & 4.28 & 0.995 & 85.52 & 1 \\
\hline 14 & The total score of the field & 3.99 & 0.603 & 79.78 & \\
\hline
\end{tabular}


Table (A-3) Statistical analysis reveals obstacles to the field of control and follow-up

\begin{tabular}{|c|c|c|c|c|c|}
\hline Sequence & Section & Avg. & $\mathbf{S}$ & RII & Ranking \\
\hline 1 & $\begin{array}{l}\text { Lack of modern equipment in } \\
\text { the field of dam safety and keep } \\
\text { abreast of global developments in this field evaluation }\end{array}$ & 4.34 & 0.795 & 86.86 & 1 \\
\hline 2 & The lack of laws in the field of application of dam safety & 4.00 & 0.909 & 80.00 & 3 \\
\hline 3 & $\begin{array}{l}\text { Weakness in matching design review } \\
\text { with the objectives of evaluating the safety of dams }\end{array}$ & 3.68 & 0.884 & 73.65 & 14 \\
\hline 4 & $\begin{array}{l}\text { Weak control over inspections and } \\
\text { periodic review of the maintenance and repair }\end{array}$ & 3.99 & 0.965 & 79.81 & 4 \\
\hline 5 & $\begin{array}{l}\text { The lack of an annual review and improve } \\
\text { the management system to evaluate } \\
\text { the safety of the dams during the operating phase }\end{array}$ & 3.89 & 0.975 & 77.88 & 10 \\
\hline 6 & $\begin{array}{l}\text { Weakness in the joints of the survey and } \\
\text { the preparation of reports and operations } \\
\text { moved from the field to the Advisory and } \\
\text { administrative bodies speed and precision } \\
\text { required and follow-up }\end{array}$ & 4.06 & 0.974 & 81.15 & 2 \\
\hline 7 & $\begin{array}{l}\text { Difficulty in control and quality management } \\
\text { during the construction of dams }\end{array}$ & 3.98 & 1.019 & 79.62 & 5 \\
\hline 8 & $\begin{array}{l}\text { The weakness of the rotating control over } \\
\text { scheduling and funding sources for operations dam } \\
\text { safety evaluation }\end{array}$ & 3.92 & 0.927 & 78.48 & 9 \\
\hline 9 & Weak control and follow-up for risk management & 3.92 & 0.930 & 76.73 & 12 \\
\hline 10 & $\begin{array}{l}\text { Lack of control and follow-up operations } \\
\text { on the operating periodic }\end{array}$ & 3.79 & 0.952 & 75.77 & 13 \\
\hline 11 & $\begin{array}{l}\text { Scarcity of control and follow-up on storage } \\
\text { operations and events congruence }\end{array}$ & 3.93 & 0.952 & 78.64 & 8 \\
\hline 12 & $\begin{array}{l}\text { Lack of conformity between the audit and } \\
\text { construction processes and designs for } \\
\text { the purposes of the amendment and conformity }\end{array}$ & 3.95 & 0.863 & 79.04 & 7 \\
\hline 13 & $\begin{array}{l}\text { The lack of review and matching during } \\
\text { the operation and maintenance with designs }\end{array}$ & 3.89 & 1.050 & 77.71 & 11 \\
\hline 14 & $\begin{array}{l}\text { Lack of a central complete control over } \\
\text { the dams and continuous follow-up via satellite }\end{array}$ & 3.97 & 1.042 & 79.43 & 6 \\
\hline 15 & The total score of the field & 3.99 & 0.567 & 78.88 & \\
\hline
\end{tabular}

